\title{
Anti-melanogenesis in B16F0 Melanoma Cells by Extract of Fermented Cordyceps militaris Containing High Cordycepin
}

\author{
Jae-Young Cha ${ }^{1}$ and Sung-Young $\mathrm{Kim}^{2}{ }^{2}$ \\ ${ }^{1}$ Technical Research Institute, Daesun Distilling Co. Ltd, Busan 619-951, Korea \\ ${ }^{2}$ Department of Food Science, Andong Science College, Andong, Gyeongsangbuk-do, 760-709, Korea
}

Received September 2, 2013 / Revised October 16, 2013 / Accepted November 13, 2013

\begin{abstract}
To find a novel skin whitening agent, the effect of cordycepin-enriched Cordyceps militaris (CMa) extract fermented by fungi on anti-melanogenesis in B16F0 mouse melanoma cells was investigated. Fermented CMa was prepared with fungi, including Monascus purpureus (Mp), Aspergillus oryzae (Ao), Aspergillus kawachii (Ak), and Rhizopus oryzae (Ro), respectively. When the content of the phenolics and the flavonoids and the activities of the antioxidant and the mushroom tyrosinase inhibition were measured in the CM fermented by Ak (AkF-CM), the highest content of the phenolics was $46 \mathrm{mg} / \mathrm{g}$ dry weight and the highest content of the flavonoids was $0.93 \mathrm{mg} / \mathrm{g}$; the highest activity of the DPPH radical scavenging was $62.74 \%$ and the highest activity of the mushroom tyrosinase inhibition was 79.97\% CMaCMa. From this result, AkF-CMa exhibited the highest mushroom tyrosinase inhibitory activity and so it was used in subsequent anti-melanogenesis. B16F0 melanoma cells were treated with $1-10 \mathrm{mg} / \mathrm{ml}$ concentrations of AkF-CMa and $200 \mu \mathrm{M}$ arbutin as the positive control. The melanin content and cell viability of the melanoma cells by arbutin treatment decreased to $43 \%$ and $92 \%$ of the control, respectively. AkF-CMa treatment at 1,3 , and $5 \mathrm{mg} / \mathrm{ml}$ concentrations decreased the extracellular melanin release induced by IBMX treatment by 35\%,45\%, and 53\%, respectively. AkF-CMa showed inhibitory activity against both intracellular tyrosinase in melanoma cells and mushroom tyrosinase. AkF-CMa reduced the protein level of tyrosinase in the IBMX-stimulated cells. These results indicate that AkF-CMa suppressed the activity and protein content of cellular tyrosinase and decreased the total melanin content in cultured B16F0 melanoma cells.
\end{abstract}

Key words : Aspergillus kawachii, B16F0 melanoma cell, cordycepin, Cordyceps militaris, tyrosinase

\section{Introduction}

Melanin is synthesized in the epidermal melanosomes of melanocytes with UV radiation in human skin and is major factor to determine skin color [23]. Melanin in skin plays important roles in the prevention of sun-induced skin injury, such as age spots, freckles, and melasma [33]. Tyrosinase is the rate-limiting enzyme for melanogenesis and plays an important role in the pathway of melanin synthesis, which is the hydroxylation of tyrosine to 3,4-dihydroxyphenylalanine (DOPA) and the subsequent oxidation of DOPA to dopaquinone [14]. Therefore, the development of tyrosinase inhibitors may be useful as a skin-whitening agent in the cosmetic industry. Recently, attention has been focused on

*Corresponding author

Tel : +82-54-851-3596, Fax : +82-54-852-9907

E-mail : ksy3596@asc.ac.kr

This is an Open-Access article distributed under the terms of the Creative Commons Attribution Non-Commercial License (http://creativecommons.org/licenses/by-nc/3.0) which permits unrestricted non-commercial use, distribution, and reproduction in any medium, provided the original work is properly cited. the use of natural products in the development of more safer and effective whitening agents [20]. Hence potent tyrosinase inhibitors have been isolated epigallocatechin-3-gallate (EGCG), (-)-epigallocatechin (EGC), kaemperol, quercetine, and luteolin from natural plants [12, 27].

In addition, melanin biosynthesis inhibitors were isolated from microbial fermentation products such as terrein from Penicillium sp. [21] and aspochalasins from solid-state culture of Aspergillus flavipes [9], which potently inhibited melanogenesis in melanocyte cells without cytotoxicity. And potential tyrosinase inhibitors were also produced as secondary metabolites of Streptomyces roseolilacinus NBRC 12815 [24], Aspergillus oryzae KFRI 00875 and 00888 strains [19]. We have also screened melanin biosynthesis inhibitors from the extracts and fermented products and found strong tyrosinase inhibitors using mushroom tyrosinase inhibitory assay in vitro [7, 22]. Moreover, C. militaris extract exhibit significant inhibition of tyrosinase activity [8]. $C$. militaris has long been used for nutraceutical and traditional medicines in eastern Asia countries and has been reported to have beneficial effects such as anti-inflammatory, anti-tumor, hypolipidemic, 
immunomodulatory, and antioxidant effect $[34,36]$. Since $C$. militaris is widespread throughout the world, this mushroom has attracted much attention from researchers.

C. militaris was also contained the bioactive compounds such as cordycepin (3'-deoxyadenosine) and 2'-deoxycoformycin [18, 25]. Additionally, previous our study newly found that cordycepin content large quantity contained by $7.42 \mathrm{mg} / \mathrm{g}$ d.w. in crossbred cordycepin-enriched C. militaris JLM 0636 and it was increased by 7-fold compared to the natural $C$. militaris [5]. Dietary supplemented with cordycepin-enriched $C$. militaris protected against orotic aicd-induced hepatotoxicity and oxidative stress in SpragueDawley rats [5]. However, there are no reports of inhibitory effects on melanogenesis in B16F0 melanoma cells by the fermented products from solid-state culture of fungi using fruiting bodies of cordycepin-enriched C. militaris JLM 0636. Therefore, present study was investigated the inhibitory activity of melanin biosynthesis in B16F0 melanoma cells by the water extract of fermented cordycepin-enriched $C$. militaris JLM 0636 by fungi.

\section{Materials and Methods}

Soled-state fermentation using fruiting bodies of
cordycepin-enriched C. militaris

The dried fruiting body of cordycepin-enriched $C$. militaris JLM0636 (CMa) used in this study were supplied by Chungwonnonsan Co., Ltd. (Gimhae, Republic of Korea). Fungal strains, Monascus purpureus KCCM 12002 (Mp), Aspergillus kawachii KCCM 32819 (Ak), Aspergillus oryzae KCCM 11372 (Ao), and Rhizopus oryzae KCCM 11273 (Ro) used for solid-state fermentation products were purchased from the Korean Culture Center of Microorganism (KCCM). Four fermented products made by cultivating these strains on moistened $\mathrm{CMa}$ at $30^{\circ} \mathrm{C}$ under $95 \%$ humidity condition for 12 days according to previous study [6]. The culture was mixed every $12 \mathrm{hr}$. Fermented CMa was obtained by heat-drying for $6 \mathrm{hr}$ and then extracted with water and stored at $4^{\circ} \mathrm{C}$ until analyzed.

\section{Measurement of total phenolic compounds}

Total phenolic compound was determined according to a modified Folin-Ciocalteu method [28]. Briefly, $2 \mathrm{ml}$ of Folin-Ciocalteu phenol regent was added to $10 \mathrm{ml}$ of fermented $\mathrm{CMa}$ at $1 \mathrm{mg} / \mathrm{ml}$ and mixed. After $5 \mathrm{~min}, 2 \mathrm{ml}$ of saturated sodium carbonate $\left(\mathrm{Na}_{2} \mathrm{CO}_{3}\right)$ solution was added and the mixture was shaken. The optimal density of the solution was measured at $725 \mathrm{~nm}$ after 60 min using a UV mini 1240 UV-VIS spectrophotometer (Shimadzu, Kyoto, Japan). Total phenolic content was calculated from a standard curve using various concentrations of chlorogenic acid prepared at the same time. Results were expressed as mg chlorogenic acid per g dry sample weight.

\section{Measurement of flavonoid contents}

Flavonoid content was determined by a colorimeter method [17]. Briefly, $0.25 \mathrm{ml}$ of fermented CMaat $1 \mathrm{mg} / \mathrm{ml}$ was mixed with $1.25 \mathrm{ml}$ of distilled water in a test tube and 0.75 $\mathrm{ml}$ of $5 \% \mathrm{NaNO}_{2}$ solution was added. After $5 \mathrm{~min}, 0.15 \mathrm{ml}$ of $10 \% \mathrm{AlCl}_{3} \cdot 6 \mathrm{H}_{2} \mathrm{O}$ was added. After $6 \mathrm{~min}, 0.5 \mathrm{ml}$ of 1 $\mathrm{M} \mathrm{NaOH}$ and $0.275 \mathrm{ml}$ of distilled water was added to the mixture. The mixture solution was mixed well and the absorbance was read immediately against the blank at $510 \mathrm{~nm}$ using a UV mini 1240 UV-VIS spectrophotometer (Shimadzu, Kyoto, Japan), and the flavonoid content was calculated from a calibration curve $\left(\mathrm{R}_{2}=0.999\right)$ obtained using $(+)$-catechin hydrate as a standard $(20-200 \mu \mathrm{g} / \mathrm{ml})$ prepared at the same time and expressed as mg catechin equivalents per $g$ of sample weight. All extracts were analyzed in triplicate.

\section{Evaluation of DPPH radical scavenging activity}

Antioxidant activity was assayed based on the radical scavenging activity using 1,1-diphenyl-2-picryl hydrazyl (DPPH) of experimental compounds by a colorimeter method [1]. DPPH (16 mg) was dissolved in $100 \mathrm{ml}$ ethanol to produce a $0.2 \mathrm{mM}$ DPPH solution. The solution was filtered with Whatman filter paper No. 2 (Toyo Roshi, Tokyo, Japan). Two milliliters of DPPH solution was added to $1 \mathrm{ml}$ of the fermented CMa solution containing $1 \mathrm{mg} / \mathrm{ml}$. After $30 \mathrm{~min}$ of incubation at room temperature, the absorbance at 528 nm was determined using a UV mini 1240 UV-VIS spectrophotometer (Shimadzu, Kyoto, Japan). The antioxidant activity was expressed as the percentage according to the following calculations:

DPPH radical scavenging activity $(\%)=[1-($ sample absorbance $528 \mathrm{~nm}$ )/control absorbance $528 \mathrm{~nm}] \times 100$

\section{Melanoma B16F0 cell culture}

Melanoma B16F0 cells were purchased from ATCC (Manassas, VA, USA), cultured in DMEM $(13.4 \mathrm{mg} / \mathrm{ml}$ Dulbecco's modified Eagle's medium, 10 mM HEPES, 100 
$\mathrm{U} / \mathrm{ml}$ penicillin, $100 \mu \mathrm{g} / \mathrm{ml}$ streptomycin, $24 \mathrm{mM} \mathrm{NaHCO}$, $\mathrm{pH} 7.2$ ) containing $10 \%$ fetal bovine serum (FBS), and incubated at $37^{\circ} \mathrm{C}$ under $5 \% \mathrm{CO}_{2}$ atmosphere. The cells were detached from culture dishes using $0.025 \%$ trypsin and 0.5 $\mathrm{mM}$ ethylenediaminetetra acetic acid (EDTA) in phosphate-buffered saline (PBS).

\section{Cell viability assay}

Cell survival was quantified by a colorimetric MTT assay that measures mitochondrial activity in viable cells. This method is based on the conversion of 3- (4,5-dimethylthiazol2-yl)-2,5-diphenyltetrazolium bromide (MTT, Sigma) to MTT-formazan crystal by mitochondrial enzyme as previously described [31]. Briefly, cells seeded at a density of $1.1 \times 10^{3} /$ cell in a 96-well plate (Corning, NY, USA), were allowed to adhere overnight. The culture medium was then replaced with fresh serum DMEM and AkF-CMa at a various concentration $(1-10 \mathrm{mg} / \mathrm{ml})$. After 3 days later, MTT stock solution and phenol-red free DMEM were added to each well, and the plate was incubated at $37^{\circ} \mathrm{C}$ for $2 \mathrm{hr}$ in an humidified $5 \% \mathrm{CO}_{2}$ incubator. After $2 \mathrm{hr}$, the medium was removed and $100 \mu \mathrm{l}$ of DMSO was added to dissolve formazan. After $10 \mathrm{~min}$, the optical density of each well was measured spectrophotometrically with a $560 \mathrm{~nm}$ filter. Results are shown from three experiments. Cell viability was expressed as percentages of that of control.

\section{Measurement of melanin concentrations in 96-well plates}

Melanoma B16F0 cells were seeded at a density of $2.6 \times 10^{3}$ cells/well in 96-well culture plates and incubated at $37^{\circ} \mathrm{C}$ under $5 \% \mathrm{CO}_{2}$ atmosphere for $24 \mathrm{hr}$. The cells were then treated with AkF-CMa followed by stimulant of IBMX (100 $\mu \mathrm{M})$ for 3days. Melanin concentrations in the cell-free culture media were spectrophotometrically measured at $400 \mathrm{~nm}$ using an ELISA reader. Results are shown from three experiments.

\section{Measurement of extracellular melanin concentrations, and microscopy}

Extracellular melanin release was measured as described previously with slight modification [29]. Briefly, B16F0 cells were incubated at a density of $1 \times 10^{5}$ cells in cell culture dish $(100 \times 20 \mathrm{~mm}$, Corning Incorporated, NY, USA) overnight. IBMX $(100 \mu \mathrm{M})$ was then added and cells were treated with various concentrations of AkF-CMa $(1-5 \mathrm{mg} / \mathrm{ml})$ in DMEM for 3 days. One hundred $\mu \mathrm{l}$ aliquots of media were then placed in 96-well plates and OD were measured at $400 \mathrm{~nm}$ using an ELISA reader. Melanin concentrations were expressed as percentages of that of control. Results are shown from three experiments. Before measuring the melanin content, cells were observed under a light microscope and photographed using a digital camera (Olympus, Tokyo, Japan).

\section{Measurement of cellular melanin concentrations}

Cellular melanin concentrations were measured as described previously with slight modification [29]. Briefly, B16F0 melanin cells were treated with AkF-CMa at various concentrations $(1-5 \mathrm{mg} / \mathrm{ml})$ for 3 days. After each incubation, cell pellets were washed with cold PBS and then dissolved in $1 \mathrm{ml}$ of $1 \mathrm{~N} \mathrm{NaOH}$ at $100^{\circ} \mathrm{C}$ for $30 \mathrm{~min}$ and then centrifuged for $20 \mathrm{~min}$ at $16,000 \times \mathrm{g}$. The optical densities of the supernatants were measured at $400 \mathrm{~nm}$ using an ELISA reader. Standard curves of synthetic melanin $(0-300 \mu \mathrm{g} / \mathrm{ml})$ were prepared in triplicate for each experiment. Results are shown from three experiments.

\section{Assay of tyrosinase activity}

Tyrosinase activity was determined as described previously with slight modification [4]. Briefly, B16F0 melanoma cells were cultured with AkF-CMa at various concentrations $(1-5 \mathrm{mg} / \mathrm{ml})$ for 3 days, the cells were washed with cold PBS and lysed with Ripa buffer. Lysates were clarified by centrifugation at $10,000 \times g$ for $10 \mathrm{~min}$. Protein concentration of supernatant was determined by the method of Bradford [3] with the Bio-Rad protein assay as specified by the manufacturer. After quantifying protein levels and the cell lysates were adjusted to the same concentration of protein with a lysis buffer. Reaction mixtures containing $90 \mu \mathrm{l}$ of each lysate (40 $\mu \mathrm{g}$ protein), $10 \mu \mathrm{l}$ of $10 \mathrm{mM}$ L-DOPA, and $90 \mu 1$ of lysis buffer were assayed on a 96-well plate. After incubation at $37^{\circ} \mathrm{C}$, the absorbance was measured at $475 \mathrm{~nm}$ using an ELISA reader every $10 \mathrm{~min}$ for at least $1 \mathrm{hr}$. Arbutin was used as a positive control.

A cell-free assay system was used to test for the direct effects of AkF-CMa on mushroom tyrosinase activity. Seventy $\mu \mathrm{l}$ of PBS containing $1 \mathrm{mg} / \mathrm{ml} \mathrm{AkF-CMa} \mathrm{were} \mathrm{mixed}$ with $20 \mu \mathrm{l}$ of $200 \mathrm{U} / \mathrm{ml}$ mushroom tyrosinase and incubated at room temperature. After $10 \mathrm{~min}$ incubation, $10 \mu \mathrm{l}$ of 10 mM L-DOPA was added to each reaction well. Following incubation for another $10 \mathrm{~min}$ at $37^{\circ} \mathrm{C}$, absorbance was then measured at $475 \mathrm{~nm}$ using an ELISA reader. Kojic acid was 
used as a positive control in cell-free assay system. The inhibitory effect of mushroom tyrosinase activity was calculated as follows: \% inhibition $=[(\mathrm{OD}$ at $475 \mathrm{~nm}$ without test substance and with mushroom tyrosinase - OD at $475 \mathrm{~nm}$ without test substance and mushroom tyrosinase)-(OD at $475 \mathrm{~nm}$ with test substance and mushroom tyrosinase - OD at $475 \mathrm{~nm}$ with test substance and without mushroom tyrosinase) $] \times 100$

\section{Western blot analysis}

Changes of melanin synthesis related tyrosinase protein in B16F0 melanoma cells after treated with AkF-CMa at 3 and $5 \mathrm{mg} / \mathrm{ml}$ were evaluated by western blot. B16F0 melanoma cells were cultured with AkF-CMa for 3 days, the cells lysed with Ripa buffer. Lysates were clarified by centrifugation at $10,000 \times \mathrm{g}$ for $10 \mathrm{~min}$. After quantifying protein levels and the cell lysates were adjusted to the same concentration of protein with a lysis buffer. Proteins were separated by $8 \%$ SDS-polyacryamide gel electrophoresis, as described previously [32]. After the gels were rinsed 3 times with TBST (10 mM Tris pH 7.5, $100 \mathrm{mM} \mathrm{NaCl}, 0.1 \%$ Tween 20), the separated proteins were transferred electrophoretically to a nitrocellulose membrane at $4{ }^{\circ} \mathrm{C}$ for $16 \mathrm{hr}$ at a constant current of $300 / 240 \mathrm{~mA} / \mathrm{cm}^{2}$. After blocking with TBST containing $10 \%$ nonfat milk for $1 \mathrm{hr}$ at room temperature, the membranes were incubated with primary goat tyrosinase antibody (C-19, Santa Cruz, USA) at room temperature for $1 \mathrm{hr}$ and then incubated with the horseradish peroxidase-conjugated anti-goat (tyrosinase, Trp-1 and Trp-2) secondary antibodies. The equivalent amount of protein was loaded and reacted with the goat polyclonal $\beta$-actin conjugated HRP antibody (I-19 SantaCruz USA), which was used as a control for protein loading. Blotted antibodies were detected by SuperSignal West Pico Chemiluminescent Substrate (Thermo
Scientific). The relative density in each reaction was quantified with a densitometer (Lumi-Imager F1, Roche, Switzerland) and a software (Lumianalyst 3.1.0).

\section{Statistical analysis}

The experimental data are presented as the mean $\pm \mathrm{SD}$, and were analyzed using one way analysis of variance (ANOVA).

\section{Results and Discussion}

Contents of phenolics and flavonoids and the activities of antioxidant and tyrosinase

Recently phytochemical studies have been identified flavonoids and phenolics as antioxidant ingredients in medicinal mushrooms, such as $C$. militaris, $C$. sinesis, $P$. japonica, and their fermentation preparations [16, 35]. These antioxidants are good inhibitors of tyrosinase activity and melanin production in melanoma cells $[8,15]$. These effects may be related to their antioxidant activity. Thus, the contents of total phenolics and flavonoids and the antioxidant activity in fermented $\mathrm{CMa}$ were also evaluated in this study. According to our results, phenolics contents of fermented CMa by Mp, Ao, Ak, and Ro strains were 35.37, 32.51, 46.00, and $25.63 \mathrm{mg} / \mathrm{g}$ dry weight basis, respectively and these contents were higher than the water extract of crossbred cordycepin-enriched $C$. militaris (Table 1). Flavonoid contents of fermented $\mathrm{CMa}$ by $\mathrm{Mp}$, Ao, Ak, and Ro strains were 0.47, $0.82,0.93$, and $0.73 \mathrm{mg} / \mathrm{g}$ dry weight, respectively (Table 1). Fermented CMa by AK (AkF-CMa) showed the highest contents of phenolics and flavonoids, but presented a similar antioxidant activity in DPPH radical scavenging. The highest tyrosinase inhibitory activity was also observed in AkF-CM a. The antioxidant activity of fermented $\mathrm{CMa}$ did not agree directly with their phenolic compound contents. $\mathrm{Gu}$ et al.

Table 1. The contents of phenolics and flavonoids and the activities of tyrosinase inhibition and DPPH radical scavenging of fermented cordycepin-enriched Cordyceps militaris extract with fungi

\begin{tabular}{lcccc}
\hline Fungi & $\begin{array}{c}\text { Phenolic content } \\
(\mathrm{mg} / \mathrm{g})\end{array}$ & $\begin{array}{c}\text { Flavonoid content } \\
(\mathrm{mg} / \mathrm{g})\end{array}$ & $\begin{array}{c}\text { Tyrosinase inhibitory } \\
\text { activity }(\%)\end{array}$ & $\begin{array}{c}\text { DPPH radical scavenging } \\
\text { activity }(\%)\end{array}$ \\
\hline $\mathrm{CMa}$ & $14.30 \pm 0.09$ & $0.99 \pm 0.16$ & $13.67 \pm 0.86$ & $42.46 \pm 0.79$ \\
$\mathrm{MpF}-\mathrm{CMa}$ & $35.37 \pm 3.05$ & $0.47 \pm 0.06^{\mathrm{b}}$ & $57.99 \pm 0.16$ & $60.42 \pm 1.10^{\mathrm{a}}$ \\
$\mathrm{AoF}-\mathrm{CMa}$ & $32.51 \pm 2.15$ & $0.82 \pm 0.03^{\mathrm{c}}$ & $44.80 \pm 1.40$ & $58.90 \pm 1.21^{\mathrm{c}}$ \\
$\mathrm{AkF}-\mathrm{CMa}$ & $46.00 \pm 2.00$ & $0.93 \pm 0.03^{\mathrm{c}}$ & $79.97 \pm 1.62$ & $62.74 \pm 1.17^{\mathrm{d}}$ \\
RoF-CMa & $25.63 \pm 3.63$ & $0.73 \pm 0.03^{\mathrm{a}}$ & $44.17 \pm 1.34$ & $61.06 \pm 2.02^{\mathrm{c}}$ \\
\hline
\end{tabular}

MpF-CMa: fermented cordycepin-enriched Cordyceps militaris (CMa) with Monascus purpureus, AoF-CMa: fermented cordycepin-enriched Cordyceps militaris (CMa) with Aspergillus oryzae, AkF-CMa: fermented cordycepin-enriched Cordyceps militaris (CMa) with Aspergillus kawachii, RoF-CMa: fermented cordycepin-enriched Cordyceps militaris (CMa) with Rhizopus oryzae. 
reported that the water extract of fermented $C$. militaris has a strong free radical scavenging activity, indicating its antioxidant activity [15]. Chien et al. reported that mushroom tyrosinase activity showed less than $25 \%$ inhibitory effect in the extracts treatment $(1 \mathrm{mg} / \mathrm{ml})$ of ethanol and water from $C$. militaris mycelia and this effect was more pronounced in water extract than in ethanol extract [8]. However, the water extract of AkF-CMa showed higher inhibition effects (44.80-79.97\%) on the mushroom tyrosinase than that of water extract from $C$. militaris mycelia above mentioned [8], which is acceptable to conclude that other factors may be involved in these properties. The fermented process affected the tyrosinase inhibition activity of $\mathrm{CMa}$, these activities of both $\mathrm{CMa}$ and fermented $\mathrm{CMa}$ were significantly related with the quantity of phenolics.

Cordycepin, known as $3^{\prime}$-deoxyadenosine, is a bioactive compound present in species of fungi belonging to the genus Cordyceps [18]. Cordycepin has a variety of biological effects such as antioxidant activity and tyrosinase inhibition in Cloudman S-91 mouse melanoma cells [5, 13, 25]. Previous our study found that cordycepin contained large quantity in crossbred C. militaris JLM 0636 by $742 \mathrm{mg} / 100 \mathrm{~g}$ d.w. and it was higher 1.7-7-fold than in other C. militaris [16, 25]. Steinberg and Whittaker reported that the melanotic stimulation by theophylline in cultures of RPMI 3460 hamster melanoma cells was prevented by cordycepin [30]. Thus, the potential anti-melanogenesis effect by AkF-CMa is probably based on the antioxidant and tyrosinase inhibitory activities by cordycepin. From these results, it is concluded that AkF-CMa containing relatively higher cordycepin has more potential antioxidative and tyrosinase inhibition effects compared to the other Cordyceps species containing relatively lower cordycepin.

Aspergillus species such as $A$. kawachii and A. oryzae, have been utilized in the traditional fermented products in Korea and Japan for more than 1,000 years [2]. Futhermore, a potent antioxidant substance has recently been produced from solid-state culture silkworm and soybean fermented with $A$. kawachii and $A$ oryzae $[6,11]$. Thus, another antioxidant and tyrosinase inhibitory properties of $C$. militaris may be due to the increased content of phenolic compounds through solid-state fermentation process. AkF-CMa may play an important role in inhibiting tyrosinase activity and melanin production. Therefore, AkF-CMa was further tested by melanin production and cellular tyrosinase assay in melanoma cells.
Effect of AkF-CMa on cell viability and melanin production

The effect of AkF-CMa on cell viability of B16F0 melanoma cells is shown in Fig. 1, which was determined using an MTT assay. B16F0 melanoma cells were treated with AkF-CMa of $1-10 \mathrm{mg} / \mathrm{ml}$ concentrations and arbutin of 200 $\mu \mathrm{M}$ in culture for cell viability for 3 days. Melanoma cell viability was expressed as the percentage value and was calculated with respect to that in the control cells. Arbutin as positive control showed no toxicity on cell viability by $91 \%$, as previously reported [26]. AkF-CMa was not cytotoxicity to $\mathrm{B} 16 \mathrm{~F} 0$ melanoma cells at low concentration range from 1-5 mg/ml, but somewhat cytotoxicity showed at higher concentrations (8 and $10 \mathrm{mg} / \mathrm{ml}$ ).

The effect of AkF-CMa on melanogenesis in B16F0 melanoma cells was evaluated by measurement of the melanin formation after 3 days of incubation which is shown in percentage value (Fig. 1). The melanin contents in B16F0 melanoma cells by arbutin decreased to $43 \%$ of the control. AkF-CMa showed a significant inhibitory effect on melanin content with concentration-dependent manner.

\section{Effect of AkF-CMa on melanin synthesis}

We determined the effect of AkF-CMa on the IBMX-mediated stimulation of melanogenesis in the B16F0 melanoma cells, and found that $100 \mu \mathrm{M}$ IBMX treatments for 3 days increased the amount of melanin detected in the extracellular media compared with negative control value (Fig.

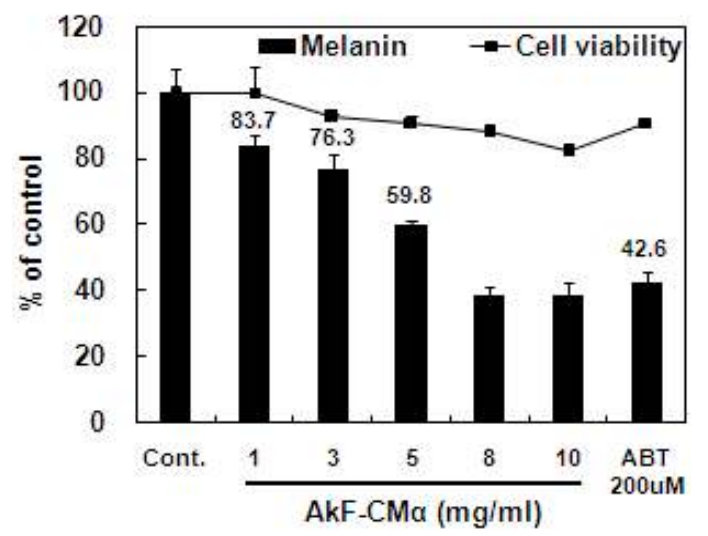

Fig. 1. Effects of AkF-CMa and arbutin on the cell viability and melanin content of $\mathrm{B} 16 \mathrm{~F} 0$ melanoma cells. AkF-CMa: the water extract of cordycepin-enriched Cordyceps militaris fermented by Aspergillus kawachii. B16F0 melanoma cells were treated with $1-10 \mathrm{mg} / \mathrm{ml} \mathrm{AkF-CMa} \mathrm{in} \mathrm{the} \mathrm{presence}$ of $100 \mu \mathrm{M}$ IBMX for 3 days. Results are means \pm SD of triplicate data. 


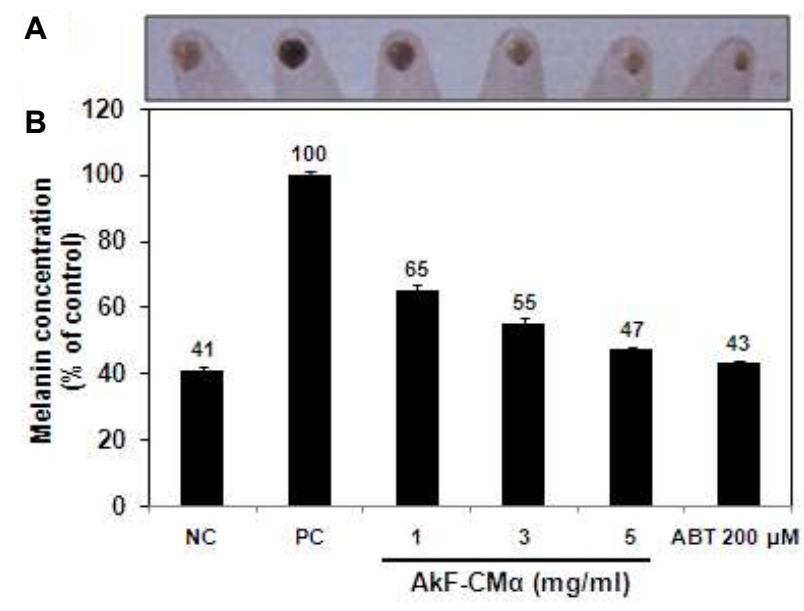

Fig. 2. Effect of AkF-CMa on melanin production in B16F0 melanoma cells. The photograph of melanin in cell pellet (A) and the melanin content in cell-free media (B) of B16F0 melanoma cells treated with 1,3 , and $5 \mathrm{mg} / \mathrm{ml} \mathrm{AkF-CMa}$ in the presence of $100 \mu \mathrm{M}$ IBMX for 3 days. Results are means \pm SD of triplicate data.

2B). AkF-CMa decreased the amount of melanin secreted into the media, reducing it to 35,45 , and $53 \%$ at 1,3 and 5 $\mathrm{mg} / \mathrm{ml}$ concentrations, respectively. Moreover, the colors of the cell pellets changed corresponding to the tested AkF-CM a (Fig. 2A). As shown in the morphological analysis of B16F0 melanoma cells under a light microscope (Fig. 3), AkF-CMa treated cells were also showed much less pigmented than positive control cells by $100 \mu \mathrm{M}$ IBMX treatment.

Effect of AkF-CMa on the activities of mushroom and cellular tyrosinase

Tyrosinase is the key enzyme in the pathway of melano- genesis and plays a regulatory role in melanin production [14]. Because melanin synthesis is ultimately regulated by tyrosinase, the direct inhibitory effect of AkF-CMa on tyrosinase was examined by mushroom tyrosinase and cellular tyrosinase in cultured B16F0 melanoma cells. As expected, kojic acid $(200 \mu \mathrm{M})$, which is well known as a direct tyrosinase inhibitor, showed a significant inhibition effect on the mushroom tyrosinase by $70 \%$ (Fig. 4). AkF-CMa showed potent inhibitory effect on the mushroom tyrosinase in a concentration-dependent manner and was more potent than kojic acid. Chien et al also reported that the $1 \mathrm{mg} / \mathrm{ml}$ water extract of $C$. militaris mycelia exerted a direct inhibitory effect on mushroom tyrosinase activity [8].

As shown in Fig. 5, AkF-CMa inhibited the cellular tyrosinase activity, which was some reduced by 1,3 , and 5 $\mathrm{mg} / \mathrm{ml}$ of AkF-CMa to 15,40 , and $43 \%$ of that in the positive control cells and this effect was more potent than arbutin. Additionally, cordycepin inhibited the melanin biosynthesis and the tyrosinase activity stimulated with theophylline, an inhibitor of cAMP-degrading phosphodiesterase [30]. This result strongly indicated that the depigmenting effect of AkF-CMa can down-regulate the expression of tyrosinase.

\section{Western Blotting of B16F0 melanoma proteins treated with $\mathrm{AkF}-\mathrm{CMa}$}

Recently new developed depigmenting agents, such as fermented Viola mandshurica and fermented rice bran extract were shown to inhibit melanogenesis by down-regulation of melanogenic proteins such as tyrosinase and MITF [10, 22]. Thus, to investigate the inhibition mechanism of melanin
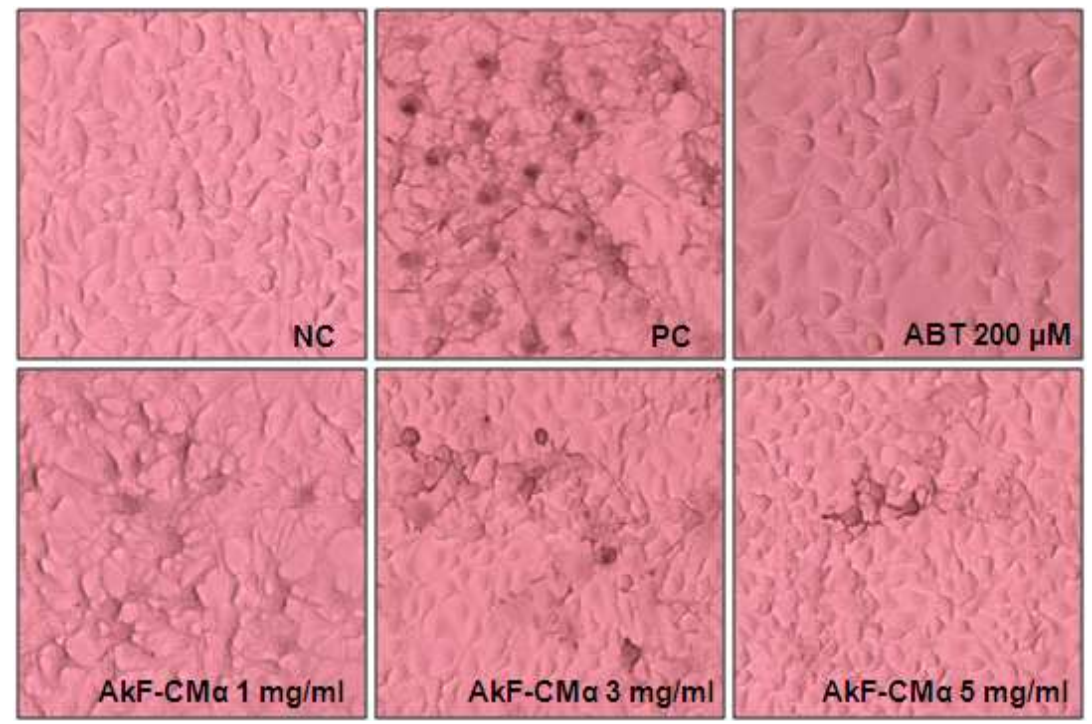

Fig. 3. Effect of AkF-CMa on cellular morphology of B16F0 melanoma cells. AkF-CMa: the water extract of cordycepin-enriched Cordyceps militaris fermented by Aspergillus kawachii. B16F0 melanoma cells were treated with 1 , 3 , and $5 \mathrm{mg} / \mathrm{ml} \mathrm{AkF-CMa} \mathrm{in} \mathrm{the}$ presence of $100 \mu \mathrm{M}$ IBMX for 3 days. 


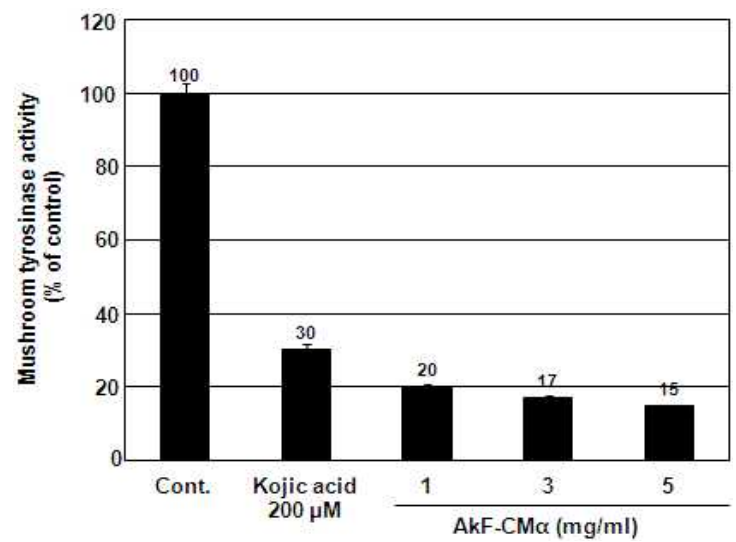

Fig. 4. Effects of AkF-CMa and kojic acid on mushroom tyrosinase inhibitory activity. AkF-CMa: The water extract of cordycepin-enriched Cordyceps militaris fermented by Aspergillus kawachii. Results are means \pm SD of triplicate data.

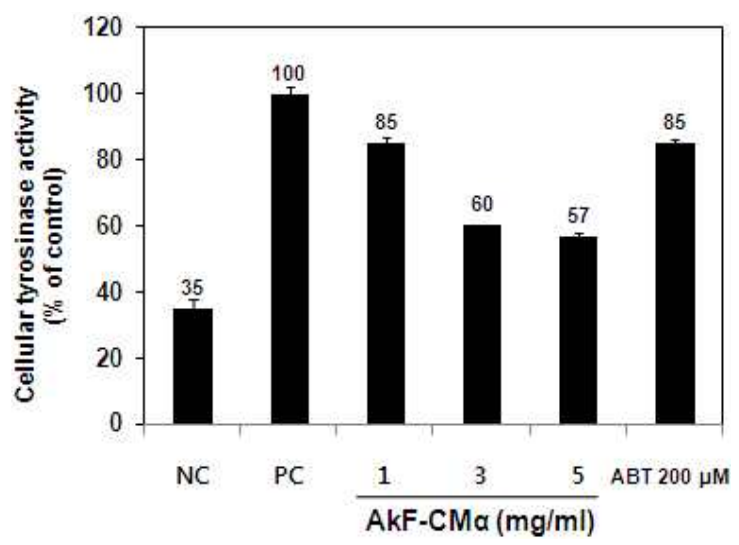

Fig. 5. Effect of AkF-CMa on cellular tyrosinase activity in B16F0 melanoma cells. AkF-CMa: The water extract of cordycepin-enriched Cordyceps militaris fermented by Aspergillus kawachii. B16F0 melanoma cells were treated with 1, 3, and $5 \mathrm{mg} / \mathrm{ml} \mathrm{AkF-CMa}$ in the presence of $100 \mu \mathrm{M}$ IBMX for 3 days. Results are means \pm SD of triplicate data.

biosynthesis by AkF-CMa, we performed western blotting against the cell protein obtained from AkF-CMa treated B16F0 melanoma cells. The protein content of tyrosinase was significantly elevated in B16 melanoma cells stimulated with IBMX as positive control, whereas AkF-CMa treatment was significantly decreased this protein content (Fig. 6), suggesting that AkF-CMa inhibits melanogenesis primarily via tyrosinase inhibition. However, the more detailed mechanism for tyrosinase inhibition in B16F0 melanoma cells remained to be clarified.

In conclusion, present study was first demonstrated that AkF-CMa suppressed cellular tyrosinase activity and protein content and melanin production in cultured B16F0 melano-

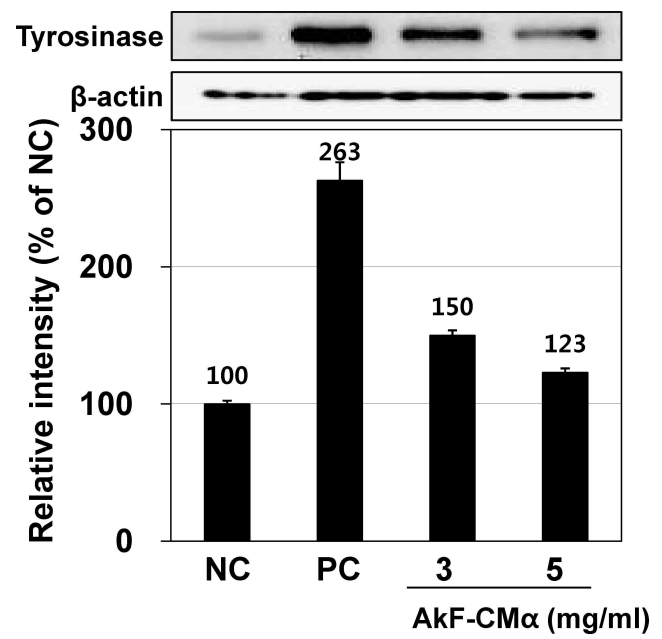

Fig. 6. Effect of AkF-CMa on the protein content of tyrosinase in B16F0 melanoma cells. AkF-CMa: The water extract of cordycepin-enriched Cordyceps militaris fermented by Aspergillus kawachii. B16F0 melanoma cells were treated with 3 and $5 \mathrm{mg} / \mathrm{ml} \mathrm{AkF-CMa} \mathrm{in} \mathrm{the} \mathrm{presence} \mathrm{of} 100$ $\mu \mathrm{M}$ IBMX for 3 days and protein contents were determined by western blotting.

ma cells.

\section{Acknowledgement}

This research was financially supported by Reinforcement Program for Andong Science College Educational Capability, 2013.

\section{References}

1. Abe, N., Murata, T. and Hirota, A. 1998. Novel DPPH radical scavengers, bisorbicillinol and demethyltrichodimerol, from a fungus. Biosci Biotechnol Biochem 62, 661-666.

2. Bennett, J. W. 2001. Aspergillus and koji: history, practice and molecular biology. SIM News 51, 65-71.

3. Bradford, M. M. 1976. A rapid and sensitive method for the quantitation of microgram quantities of protein utilizing the principle of protein-dye binding. Anal Biochem 72, 248-254.

4. Busca, R., Bertolotto, C. Ortonne, J. P. and Ballotti, R. 1996. Inhibition of the phosphatidylinositol 3-kinase/p70(S6)-kinase pathway induces B16 melanoma cell differentiation. $J$ Biol Chem 271, 31824-31830.

5. Cha, J. Y., Ahn, H. Y., Heo, S. J., Kang, M. J., Lee, J. H., Park, S. H., Jeong, Y. K. and Cho, Y. S. 2011. Improvement effect of cordycepin-enriched Cordyceps militaris JLM 0636 powder against orotic acid-induced fatty liver in rats. J Life Sci 23, 789-795.

6. Cha, J. Y., Kim, Y. S., Kang, P. D., Ahn, H. Y., Eom, K. E. and Cho, Y. S. 2010. Biological activity and chemical char- 
acteristics of fermented silkworm powder by mold. J Life Sci 20, 237-244.

7. Cha, J. Y., Yang, H. J., Jeong, J. J., Seo, W. S., Park, J. S., Ok, M. and Cho, Y. S. 2010. Tyrosinase inhibition activity and antioxidant capacity by fermented products of some medicinal plants. J Life Sci 20, 940-947.

8. Chien, C. C., Tsai, M. L., Chen, C. C., Chang, S. J. and Tseng, C. H. 2008. Effects on tyrosinase activity by the extracts of Ganoderma lucidum and related mushrooms. Mycopathologia 166, 117-120.

9. Choo, S. J., Yun, B. S., Ryoo, I. J., Kim, Y. H., Bae, K. H. and Yoo, I. D. 2009. Aspochalasin I, a melanogenesis inhibitor from Aspergillus sp. J Microbiol Biotechnol 19, 368-371.

10. Chung, S. Y., Seo, Y. K., Park, J. M., Seo, M. J., Park, J. K., Kim, J. W. and Park, C. S. 2009. Fermented rice bran downregulates MITF expression and leads to inhibition of alpha-MSH-induced melanogenesis in B16F1 melanoma. Biosci Biotechnol Biochem 73, 1704-1710.

11. Esaki, H., Kawakishi, S., Morimitsu, Y. and Osawa, T. 1999. New potent antioxidative o-dihydroxylisoflavones in fermented Japanese soybean products. Biosci Biotechnol Biochem 63, 1637-1639.

12. Fujii, T. and Saito, M. 2009. Inhibitory effect of quercetin isolated from rose hip (Rosa canina L.) against melanogenesis by mouse melanoma cells. Biosci Biotechnol Biochem 73, 1989-1993.

13. Fuller, B. B., Lunsford, J. B. and Iman, D. S. 1987. Alpha-melanocyte-stimulating hormone regulation of tyrosinase in Cloudman S-91 mouse melanoma cell cultures. J Biol Chem 262, 4024-4033.

14. Galus, R., Niderla, J., Sladowski, D., Sajjad, E., Włodarski, K. and Jóźwiak, J. 2010. Fluvastatin increases tyrosinase synthesis induced by alpha-melanocyte-stimulating hormone in B16F10 melanoma cells. Pharmacol Rep 62, 164-169.

15. Gu, Y. X., Song, Y. W., Fan, L. Q. and Yuan, Q. S. 2007. Antioxidant activity of natural and cultured Cordyceps sp. Zhongguo Zhong Yao Za Zhi 32, 1028-1031.

16. Gursoy, N., Sarikurkcu, C., Cengiz, M. and Solak, M. H. 2009. Antioxidant activities, metal contents, total phenolics and flavonoids of seven Morchella species. Food Chem Toxicd 47, 2381-2388.

17. Jia, Z., Tang, M. and Wu, J. 1999. The determination of flavonoid contents in mulberry and thier scavenging effects on superoxide radicals. Food Chem 64, 555-559.

18. Johns, D. G., and Adamson, R. H. 1976. Enhancement of the biological activity of cordycepin ( $3^{\prime}$-deoxyadenosine) by the adenosine deaminase inhibitor 2'-deoxycoformycin. Biochem Pharmacol 25, 1441-1444.

19. Jung, S. W., Han, D. S., Kim, S. J. and Chun, M. J. 1996. Fermentation of tyrosinase inhibitor in mushroom media. Kor J Appl Microbiol Biotechnol 24, 227-233.

20. Kim, S. J., Heo, M. Y., Bae, K. H., Kang, S. S. and Kim, H. P. 2003. Tyrosinase inhibitory activity of plant extracts (III): Fifty Korean indigenous plants. J Appl Pharmacol 11, 245-248.

21. Kim, W. G., Ryoo, I. J., Park, S. H., Kim, D. S., Lee, S. K.,
Park, K. C. and Yoo, I. D. 2005. Terrein, a melanin biosynthesis inhibitor, from Penicillium sp. 20315. J Microbiol Biotechnol 15, 891-894.

22. Kwak, Y. J., Kim, K. S. Kim, K. M. Yu, Chung, H. Y. E., Kim, S. J., Cha, J. Y., Lee, Y. C. and Lee, J. H. 2011. Fermented Viola mandshurica inhibits melanogenesis in B16 melanoma cells. Biosci Biotechnol Biochem 75, 841-847.

23. Mishima, Y. 1994. Molecular and biological control of melanogenesis through tyrosinase genes and intrinsic and extrinsic regulatory factors. Pigment Cell Res 7, 376-387.

24. Nakashima, T., Anzai, K., Kuwahara, N., Komaki, H., Miyadoh, S., Harayama, S., Tianero, M. D., Tanaka, J., Kanamoto, A. and Ando, K. 2009. Physicochemical characters of a tyrosinase inhibitor produced by Streptomyces roseolilacinus NBRC 12815. Biol Pharm Bull 32, 832-836.

25. Oh, S. W., Kim, S. H., Song, H. N. and Han, D. S. 2003. Comparative chemicals compositions of four Techukaso. Korean J Food Sci Technol 35, 15-22.

26. Sato, K., Kakahashi, H., Iraha, K. and Toriyama, M. 2008. Down-regulation of tyrosinase expression by acetylsalicylic acid in murin B16 melanoma. Biol Pharm Bull 31, 33-37.

27. Sato, K. and Toriyama, M. 2009. Depigmenting effect of catechins. Molecules 14, 4425-4432.

28. Singleton, V. L. and Rossi, J. A. 1965. Colorimetry of total phenolic with phosphomolybdic phosphotungstic acid reagents. Am J Enol Viticult 16, 144-158.

29. Smalley, K. and Eisen, T. 2000. The involvement of p38 mitogen-activated protein kinase in the alpha-melanocyte stimulating hormone (alpha-MSH)-induced melanogenic and anti-proliferative effects in B16 murine melanoma cells. FEBS Lett 476, 198-202.

30. Steinberg, M. L. and Whittaker, J. R. 1976. Stimulation of melanotic expression in a melanoma cell line by theophylline. J Cell Physiol 87, 265-275.

31. Tada, H., Shiho, O., Kuroshima, K., Koyama, M. and Tsukamoto, K. 1986. An improved colorimetric assay for interleukin 2. J Immunol Methods 93, 157-165.

32. Vasiliou, V., Lee, J., Pappa, A. and Petersen, D. R. 2000. Involvement of p65 in the regulation of NF-kappaB in rat hepatic stellate cells during cirrhosis. Biochem Biophys Res Commun 273, 546-550.

33. Yamaguchi, Y. and Hearing, V. J. 2009. Physiological factors that regulating skin pigmentation. Biofactors 35, 193-199.

34. Yang, B. K., Ha, J. Y., Jeong, S. C., Das, S., Yun, J. W., Lee, Y. S., Choi, J. W. and Song, C. H. 2000. Production of exo-polymers by submerged mycelial culture of Cordyceps militaris and its hypolipidemic effect. J Microbiol Biotechnol 10, 784-788.

35. Yoon, M. R., Nam, S. H. and Kang, M. Y. 2008. Antioxidative and antimutagenic activities of $70 \%$ ethanolic extracts from four fungal mycelia-fermented specialty rices. J Clin Biochem Nutr 43, 118-125.

36. Yu, R., Yang, W., Song, L., Yan, C., Zhang, Z. and Zhao, Y. 2007. Structural characterization and antioxidant activity of a polysaccharide from the fruiting bodies of cultured Cordyceps militaris. Carbohydr Polym 70, 430-436. 
초록 : Cordycepin-고함유 동충하초(Cordyceps militaris) 발효 추출물의 미백효과

차재영 ${ }^{1}$ 김성영 ${ }^{2} \star$

(대선주조(주) 기술연구소, ${ }^{2}$ 안동과학대학교 식품계열)

본 연구는 Monascus purpureus (Mp), Aspergillus oryzae (Ao), Aspergillus kawachii (Ak) 및 Rhizopus oryzae (Ro) 균주로 Cordycepin-고함유 동충하초(Cordyceps militaris)(CMa)를 발효시켜 수용성 추출물을 얻어 페놀화합물 및 플라보노이드 농도와 항산화 및 티로시나제 저해 활성을 측정한 결과 $\mathrm{Ak}$ 로 발효시킨 $\mathrm{CMa}(\mathrm{AkF}-\mathrm{CMa})$ 에서 각각 $46 \mathrm{mg} / \mathrm{g}$ 및 $093 \mathrm{mg} / \mathrm{g}$ 과 $6274 \%$ 및 7997\%로 가장 우수한 효과를 나타내었다. 이러한 결과로부터 AkF-CMa를 선택하여 멜라닌 세포(B16F0 mouse melanoma cell)에서 미백효과를 검토하였다. 양성 대조구 arbutin 처리 B16F10 melanoma 세포는 92\% 이상의 세포 생육과 $43 \%$ 의 멜라닌 생성 억제 효능을 보였고, AkF-CMa 1, 3 및 $5 \mathrm{mg} / \mathrm{ml}$ 처리 시 멜라닌 생성은 각각 35,45 및 $53 \%$ 억제되었다. 또한 AkF-CMa은 멜라닌 세포 내 tyrosinase 활성과 mushroom tyrosinase 활성 모두를 저해시켰고, 멜라닌 생성 관련 tyrosinase 단백질 발현량도 무첨가군에 비해 처리 농도 의존적으로 억제되었다. 이상의 결과에 따라 Aspergillus kawachii 균주로 발효시킨 Cordycepin-고 함유 동충하초(Cordyceps militaris)의 수용성 추출물은 미백 화장품 소재로 개발 가능성이 높은 것으로 사료된다. 